\title{
Plants with Hypoglycemic Effect Cultivated in Medicinal Garden from Umuarama, Paraná-Brazil: A Review
}

\begin{abstract}
Joice Karina Otênio, Geysse Kelle de Oliveira, Rosselyn Gimenes Baisch, Guilherme Donadel, Emerson Luiz Botelho Lourenço, Odair Alberton (Corresponding author), Giuliana Zardeto Sabec, Ezilda Jacomassi

Programa de Pós-graduação em Plantas Medicinais e Fitoterápicos na Atenção Básica. Laboratório de Pesquisa Pré Clínica de Produtos Naturais e Bioativos, Universidade Paranaense - UNIPAR, Praça Mascarenhas de Moraes, 4282, Umuarama, PR, Brazil.
\end{abstract}

E-mail: odair@prof.unipar.br

Received: July 13, 2020

doi:10.5296/jas.v8i4.17349
Accepted: August 4, 2020 Published: August 5, 2020

URL: https://doi.org/10.5296/jas.v8i4.17349

\begin{abstract}
The present study was carried out through a bibliographic survey of medicinal species, Asystasia gangetica, Catharanthus roseus, Arctium minus, Cynara scolymus, Anredera baselloides, Opuntia ficus-indica, Carica papaya, Ipomoea carnea, Ocimum gratissimum, Abelmoschus esculentus, Musa paradisiaca, Psidium cattleyanum, Syzygium cumini, Bougainvillea glabra, Bougainvillea spectabilis, Phyllanthus niruri, Capsicum baccatum var. pendulum and Zingiber officinale grown in the medicinal garden of Campus 2 of Universidade Paranaense, located in Umuarama, Paraná State, Brazil. The following databases were used for the bibliographic review: Scielo, Medline/Pubmed, and Google Scholar. All the species presented have hypoglycemic activity verified with preclinical and/or clinical pharmacological studies and have great potential for use in the treatment of diabetes or in combination with allopathic drugs. However, despite the pharmacological records found, additional scientific investigations are still needed to be able to use these species more safely and effectively.
\end{abstract}

Keywords: medicinal plants, diabetes mellitus, pharmacological activity, Antidiabetic

\section{Introduction}

The use of medicinal plants in the treatment of diseases is a practice as old as humanity itself. 
The peoples of ancient civilizations already used plants to treat various diseases, and their knowledge was passed on from generation to generation (Feijó et al., 2012).

Over time and the advancement of allopathic medicine, these values have been lost, giving way to more modern medicines. However, it is known that today new forms of treatment using plants have been sought and new research has been carried out (Sales; Sartor; Gentilli, 2015).

Thus, public policies on the use of medicinal plants and herbal medicines were created by the Brazilian government, so that the population can achieve safe, effective and quality access to these therapeutic resources (Brasil, 2016).

On May 3, 2006, the Ministry of Health Ordinance No. 971 was published, approving the National Policy on Integrative and Complementary Practices (NPICP), which provides support for the implementation of the national list of medicinal plants and herbal medicines, in addition, recognizes the use of these therapeutic options as an official treatment practice and promotes inclusion to users of the Unified Health System (SUS). In the same year, Decree 5,813, of June 22, 2006, on the National Policy on Medicinal Plants and Phytotherapics, which encourages research associated with technological development, which aims to ensure the effectiveness of treatments for low-severity diseases as well as for treatment of chronic diseases, including diabetes (Brasil, 2006).

Diabetes mellitus (DM) is a chronic health condition characterized by high levels of glucose in the bloodstream and can be classified as type 1, also known as insulin-dependent, which is characterized by a deficiency in insulin secretion and type 2 , triggered by a defect in the action of this hormone, when insulin is found, but its action is hampered due to obesity, which is known as insulin resistance (Martins et al., 2019).

DM type 2 is also called adult diabetes, seen in most cases of the disease, normally affecting obese people over 40 years old, however, it is currently common for it to appear in young people, which can occur due to lifestyle, for the contemporary fast-food diet, which is rich in sodium, sugar and fats, in addition to the sedentary lifestyle and stress of urban life (Faludi et al., 2017).

It is a disease that, if not properly treated, can progress to death due to hyperglycemic crisis, lower limb amputation, terminal kidney disease, acute myocardial infarction and stroke (Tschiedel et al., 2014). In addition, considering the current pandemic caused by the new Coronavirus (COVID-19), diabetic patients are more likely to develop complications from this viral infection. However, for diabetics with controlled blood glucose levels, the chances of worsening are lower, and may be similar to that of people without diabetes (Sociedade Brasileira de Diabetes, 2020).

Researchers estimate that the number of diabetics, in the year 2030, will be 472 million individuals, worldwide, which may compromise the development and economic growth of all countries (Tabák et al., 2012).

The prevalence of arterial hypertension and dyslipidemia increases the risk of developing 
atherosclerotic cardiovascular disease in patients with DM 2. Recent clinical trials have shown the importance of using treatments with active substances that are hypolipidemic, antihypertensive and hypoglycemic in reducing cardiovascular diseases, as the control of these risk factors and the maintenance of the normal glycemic index is essential to prevent the evolution of the disease (Almourani et al., 2019).

In addition, there are some effective measures that promote quality of life and decrease health problems, such as regular physical exercise, adoption of healthy eating habits, weight loss, sufficient amount of sleep, behavioral support and smoking cessation (Garber et al., 2019).

Low adherence to pharmacological treatment for chronic diseases is a reality in Brazil, one of the determining factors are socioeconomic limitation, in addition to individual characteristics of each patient (Tavares et al., 2016). In this context, medicinal plants have represented an important tool in the treatment and prevention of diseases, as they can be used with low cost compared to conventional treatments and with better acceptance by the population (Zeni et al., 2017).

Medicinal plants with the hypoglycemic activity can be associated with the use of insulin or oral drugs, is used to control blood glucose. It is a way to reduce the number of daily administrations of these drugs, coming from products of the pharmaceutical industry and consequently decreases the expenses of diabetic people (Urban; Swiech; Miguel, 2019). However, this association of medicines with plants must be made with the accompaniment of a trained health professional, in order to avoid problems that compromise the patient's health, and that promote the rational use of plants (Nicoletti et al., 2007).

In this context, the Universidade Paranaense (UNIPAR) encourages research with medicinal plants, wherein 1996 the Medicinal Garden of Campus 2 of UNIPAR located in Umuarama PR was implemented, covering an area of $30,000 \mathrm{~m}^{2}$. Through surveys carried out, it is estimated that the Horto comprises about 450 species, wherein a floristic survey carried out between 2008 and 2011, 333 species were cataloged, among which medicinal plants are predominant (Canzi et al., 2012).

Therefore, considering the importance of treatment and the risks that diabetes brings to health, the present study aimed to carry out a bibliographic survey of species with hypoglycemic activity cultivated in the Medicinal Garden of Campus 2 at UNIPAR.

\section{Method}

The present review was carried out through a bibliographic survey of plant species, with hypoglycemic pharmacological activity, from the families Acanthaceae, Apocynaceae, Asteraceae, Bassellaceae, Cactaceae, Caricaceae, Convolvulaceae, Lamiaceae, Malvaceae, Musaceae, Myrtaceae, Nyctaginaceae, Nyctaginaceae and Phyllant Zingiberaceae, grown in the Medicinal Garden on Campus 2 of Universidade Paranaense, located in Umuarama, Paraná Stade, Brazil.

The following databases were used: SciELO (Scientific Electronic Library Online), Medline/Pubmed and Google Scholar where the keywords ethnobotany, ethnopharmacology, 
pharmacological action, chemical composition, diabetes, antidiabetics, hypoglycemic effect and the names were searched of each species. The search in the Missouri Botanical Garden database, which follows the classification system according to the Angiosperm Phylogine Group (APG), served to review the scientific names of each species and their respective authors (Tropicos, 2020).

\section{Results and Discussion}

Eighteen species were found, distributed in a total of 15 families, Asystasia gangetica (L) T. Anderson (Acanthaceae), Catharanthus roseus (L.) G. Don (Apocynaceae), Arctium minus (Hill) Bernh. and Cynara scolymus L. (Asteraceae), Anredera baselloides (Kunth) Baill (Bassellaceae), Opuntia ficus-indica (L.) Mill (Cactaceae), Carica papaya L. (Caricaceae), Ipomoea carnea Jacq. (Convolvulaceae), Ocimum gratissimum L. (Lamiaceae), Abelmoschus esculentus (L.) Moench (Malvaceae), Musa paradisiaca L. (Musaceae), Psidium cattleyanum Sabine and Syzygium cumini (L.) Skeels (Myrtaceae), Bougainisy and glabra Bougainvillea spectabilis Willd. (Nyctaginaceae), Phyllanthus niruri L. (Phyllantaceae), Capsicum baccatum var. pendulum (Willd.) Eshbaugh (Solanaceae) and Zingiber officinale Roscoe (Zingiberaceae). Since all species are cultivated in the Horto Medicinal of UNIPAR and have pre-clinical and/or clinical studies, demonstrating hypoglycemic activity (Table 1). 
Table 1. Data found on each species, family, scientific name, Brazilian popular name, category of use, part of the plant used for diabetes, chemical compounds and the references

\begin{tabular}{|c|c|c|c|c|c|}
\hline Family / Scientific name & Popular name & Use category & Part used & Chemical compounds & References \\
\hline $\begin{array}{l}\text { Acanthaceae } \\
\text { Asystasia gangetica L. T } \\
\text { Anderson }\end{array}$ & T. Asistasia-branca & $\begin{array}{l}\text { Medicinal } \\
\text { Ornamental }\end{array}$ & Shoots & $\begin{array}{l}\text { Flavonoids, alkaloids, } \\
\text { glycosides, tannins, saponins } \\
\text { and phytosterols }\end{array}$ & $\begin{array}{l}\text { Cavalcanti et al. } \\
\text { (2004); Kumar et al. } \\
(2010)\end{array}$ \\
\hline $\begin{array}{l}\text { Apocynaceae } \\
\text { Catharanthus roseus L. G. Don }\end{array}$ & Vinca-Rosa & Medicinal & Shoots & Vinblastine and vincristine & $\begin{array}{l}\text { Nammi et al. } \\
(2003) \text {; Brandão et } \\
\text { al. (2010) }\end{array}$ \\
\hline $\begin{array}{l}\text { Asteraceae } \\
\text { Arctium minus (Hill) Bernh. }\end{array}$ & Bardana & Medicinal & Leaf and root & - & Cavalli et al. (2007) \\
\hline $\begin{array}{l}\text { Asteraceae } \\
\text { Cynara scolymus L. }\end{array}$ & Alcachofra & Medicinal & Shoots & $\begin{array}{l}\text { Phenolic acids, sesquiterpenes } \\
\text { and flavonoids }\end{array}$ & $\begin{array}{l}\text { Noldin et al. (2003); } \\
\text { Heidarian and } \\
\text { Soofiniya (2011); } \\
\text { Salem et al. (2017) }\end{array}$ \\
\hline $\begin{array}{l}\text { Bassellaceae } \\
\text { Anredera baselloides (Kunth } \\
\text { Baill }\end{array}$ & th) Bertalha & Medicinal & Shoots & Flavonoids & $\begin{array}{l}\text { Sukandar; } \\
\text { Qowiyyah and } \\
\text { Larasari (2013); } \\
\text { Djamil et al. (2017) }\end{array}$ \\
\hline $\begin{array}{l}\text { Cactaceae } \\
\text { Opuntia ficus-indica L. Mill }\end{array}$ & Palma-do-nordeste & Medicinal & $\begin{array}{l}\text { Fruits, seeds } \\
\text { and stem }\end{array}$ & $\begin{array}{l}\text { Phenolic compounds, flavonoids } \\
\text { and betalains }\end{array}$ & $\begin{array}{l}\text { Frati, Jiménez and } \\
\text { Ariza (1990); } \\
\text { Barbera (2001); } \\
\text { Butterweck et al. } \\
\text { (2011) }\end{array}$ \\
\hline $\begin{array}{l}\text { Caricaceae } \\
\text { Carica papaya } \mathrm{L} .\end{array}$ & Mamão & Fruitful & Shoots & $\begin{array}{l}\text { Alkaloids, steroids, quinones } \\
\text { and tannins }\end{array}$ & $\begin{array}{l}\text { Maniyar and } \\
\text { Bhixavatimath } \\
\text { (2012); } \\
\text { Juaréz-Rojop et al. } \\
\text { (2014) }\end{array}$ \\
\hline $\begin{array}{l}\text { Convolvulaceae } \\
\text { Ipomoea carnea Jacq. }\end{array}$ & Algodão-bravo & Ornamental & Shoots & $\begin{array}{l}\text { Phenolic compounds, flavonoids } \\
\text { and tannins }\end{array}$ & $\begin{array}{l}\text { Khan et al. (2014); } \\
\text { Khan et al. (2015) }\end{array}$ \\
\hline $\begin{array}{l}\text { Lamiaceae } \\
\text { Ocimum gratissimum } \mathrm{L} .\end{array}$ & Alfavaca & Medicinal & Shoots & $\begin{array}{l}\text { Tannins, steroids, terpenoids, } \\
\text { flavonoids and cardiac } \\
\text { glycosides }\end{array}$ & $\begin{array}{l}\text { Akinmoladun et al. } \\
\text { (2007); Okon et al. } \\
\text { (2012); Oguanobi, } \\
\text { Chijioke and Ghasi } \\
\text { (2012) }\end{array}$ \\
\hline $\begin{array}{l}\text { Malvaceae } \\
\text { Abelmoschus esculentus } \\
\text { Moench }\end{array}$ & L. Quiabo & Vegetable & Fruit and seed & Microemulient polysaccharides & $\begin{array}{l}\text { Adelakun et al. } \\
(2010) ; \quad \text { Soares } \\
(2010) ; \text { Sabitha et } \\
\text { al. } \\
\text { Sabitha, } \\
\text { Panneerselvam and } \\
\text { Ramachandran } \\
\text { (2012); Dos Santos, } \\
\text { Costa and Santos } \\
(2014)\end{array}$ \\
\hline $\begin{array}{l}\text { Musaceae } \\
\text { Musa paradisiaca L. }\end{array}$ & Banana-nanica & Fruitful & $\begin{array}{l}\text { Fruits and } \\
\text { roots }\end{array}$ & $\begin{array}{l}\text { Serotonin, norepinephrine, } \\
\text { tryptophan, indole compounds, } \\
\text { tannin, starch, iron, } \\
\text { crystallisable and } \\
\text { non-crystallizable sugars, } \\
\text { vitamin C, B vitamins, } \\
\text { albuminoids, fats and minerals }\end{array}$ & $\begin{array}{l}\text { Usha, Vijayammal } \\
\text { and Kurup (1989); } \\
\text { Mallick et al. } \\
\text { (2007); Imam and } \\
\text { Akter(2011) }\end{array}$ \\
\hline $\begin{array}{l}\text { Myrtaceae } \\
\text { Psidium cattleyanum Sabine }\end{array}$ & Araçá & Fruitful & Shoots & $\begin{array}{l}\text { Catechins, steroids, phenolic } \\
\text { compounds, flavonoids and } \\
\text { saponins }\end{array}$ & $\begin{array}{lr}\text { Pacheco } & (2015) ; \\
\text { Faleiro et al. } & (2016) ; \\
\text { De Souza } & \text { Cardoso } \\
(2018) ; & \text { Pereira } \\
(2018) & \end{array}$ \\
\hline $\begin{array}{l}\text { Myrtaceae } \\
\text { Syzygium cumini (L.) Skeels }\end{array}$ & Jambolão & Fruitful & $\begin{array}{l}\text { Bark, leaves, } \\
\text { seeds }\end{array}$ & $\begin{array}{l}\text { Alkaloids, glycosides, } \\
\text { triterpenoids, steroids, saponins, } \\
\text { flavonoids and tannins }\end{array}$ & $\begin{array}{l}\text { Kumar et al. } \\
(2013) \text {; Alam et al. } \\
(2012) ; \text { Chaudhary } \\
\text { and Mukhopadhyay } \\
(2012) \text {; Kamal } \\
(2014)\end{array}$ \\
\hline $\begin{array}{l}\text { Nyctaginaceae } \\
\text { Bougainvillea glabra Choisy }\end{array}$ & Primavera & $\begin{array}{l}\text { Ornamental } \\
\text { Leaf }\end{array}$ & $\begin{array}{l}\text { Ornamental } \\
\text { Leaf }\end{array}$ & $\begin{array}{l}\text { Flavonoids, phenolic } \\
\text { compounds and alkaloids }\end{array}$ & $\begin{array}{l}\text { Adebayo et al. } \\
(2009) \text {; Soni et al. }\end{array}$ \\
\hline
\end{tabular}




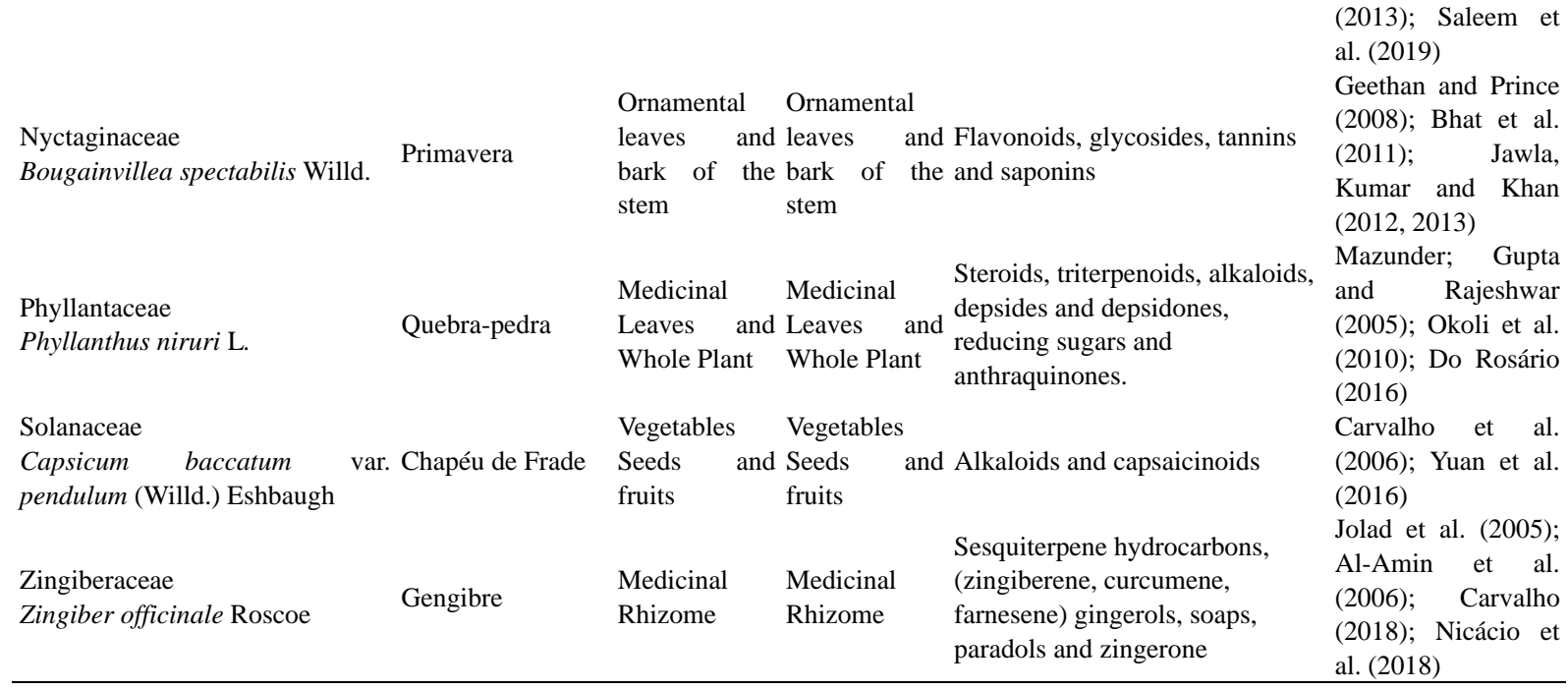

\section{Acanthaceae}

Asystasia gangetica (L) T. Anderson, popularly known as Chinese violet, has its origin in India and Malaysia, being cultivated in tropical regions (Lorenzi; Matos, 2002). It is a plant for ornamental use in squares, parks and nurseries (Cavalcanti et al., 2004).

For the first time, a study was carried out by Kumar et al. (2010), to demonstrate the hypoglycemic, hypolipidemic and antioxidant effects of $A$. gangetica leaves. In this study, isolated ethanolic extracts were used and in combination with Morus indica extract, in diabetic rats induced by alloxane. The results showed that A. gangetica had an important the hypoglycemic and hypolipidemic effect, as it significantly reduced the concentration of glucose, total cholesterol and triglycerides (Kumar et al., 2010).

In the same study, it also performed the phytochemical analysis of A. gangetica, where the presence of flavonoids, alkaloids, glycosides, tannins, saponins and phytosterols were detected (Kumar et al., 2010).

\section{Apocynaceae}

Catharanthus roseus (L.) G. Don, known as Madagascar periwinkle or "good night" has its origin on the island of Madasgacar (Indian Ocean), where it is popularly used to treat diabetes (Lorenzi; Matos, 2002).

Nammi et al. (2003) carried out a study with juice from the leaves of $C$. roseus in diabetic rabbits induced by alloxane, where the animals were treated for 24 hours and the blood samples collected, every 2 hours, after the oral ingestion of the plant juice. The results showed that there was a significant reduction in glycemia of $19.6 \%(8 \mathrm{~h}), 31.4 \%(18 \mathrm{~h})$ and $36.5 \%(20 \mathrm{~h})$, during the ingestion of $C$. roseus juice, in comparison with glibenclamide which reduced $34.9 \%$ (8h).

In this sense, the most likely mechanism of action of $C$. roseus, responsible for the hypoglycemic activity, may have been mediated by the increase in insulin secretion of Langerhans $\beta$ cells or by an extra pancreatic mechanism (Nammi et al., 2003).

In addition, $C$. roseus presents in its chemical composition the alkaloids vincristine and 
vinblastine, when isolated from the plant, has an important chemotherapeutic action (Brandão et al., 2010).

\section{Asteraceae}

Cynara scolymus L., popularly known as artichoke, it originates from the Mediterranean and its cultivation occurs in all countries with a subtropical climate (Lorenzi; Matos, 2002). Its main use is in human food, however, it can also be used as a source of biomass, fodder for cattle, raw material in preparations of alcoholic beverages, as a source of inulin. In addition, the pharmacopoeia describes several functions of this plant that are beneficial to health (Portis et al., 2005).

A study carried out on the chemical composition and biological effects of C. scolymus leaves grown in Brazil, observed the presence of chemical compounds that play important roles in the body, such as phenolic acids, flavonoids and sesquiterpenes (Noldin et al., 2003). The same author points out that the major component of this species is cinarina, however a cultivation carried out in Brazil showed a small amount of this chemical compound, this is due to environmental and seasonal factors that can interfere with the quantity and the quality of its chemical composition.

In order to assess the effects of $C$. scolymus on blood glucose, Heidarian; Soofiniya (2011), carried out a study with diabetic rats induced by streptozotocin, where an aqueous extract of the leaves was used in the dosage of 200 and $400 \mathrm{mg} \mathrm{kg}^{-1}$, observing at the end of the experiment, the animals obtained a significant reduction in fasting glucose, total cholesterol, triglycerides, LDL cholesterol (low density lipoprotein) and VLDL cholesterol (very low-density lipoprotein), and increased plasma antioxidant capacity in treated diabetic animals (Heidarian; Soofiniya, 2011).

Salem et al. (2017) evaluated in their study the protective effect of the ethanolic extract of the leaves of $C$. scolymus on oxidative stress in diabetic rats, induced by alloxane. In this experiment, they demonstrated a significant decrease in $\alpha$-amylase, glucose, total cholesterol, LDL cholesterol and triglycerides, suggesting that $C$. scolymus has hypoglycemic properties partially mediated by antioxidant and hypolipidemic effects (Salem et al., 2017).

Arctium minus (Hill) Bernh., popularly known as burdock, has its origin in Europe, is naturalized in southern Brazil, is considered a weed in orchards and land (Lorenzi; Matos, 2002).

A study by Cavalli et al. (2007), verified the hypoglycemic activity of the crude extract of the leaves and roots of $A$. minus, in diabetic rats induced by alloxane. After the treatment of the animals, it was shown that the crude extract of the roots reduced glycemic levels by $5.8 \%$, the crude extract of the leaves decreased by $6.2 \%$ and the positive control glibenclamide decreased by $6.2 \%$. Thus, this result demonstrates that the extract of the leaves and roots have similar effects to the reference drug glibenclamide, proving the hypoglycemic activity of this species (Cavalli et al., 2007). 


\section{Bassellaceae}

Anredera baselloides (Kunth) Baill, is a vine known popularly as bertalha, very common in several Brazilian states, found in abandoned lands, coffee plantations and orchards. It is considered a weed, due to its easy propagation, however, its leaves, aerial tubers and rhizomes are edible (Kinupp; Amaro; Barros, 2004).

In the bibliographic survey carried out with this species, only published articles are found, which demonstrate antidiabetic activity, with its synonym Anredera cordifolia (Ten.) Steenis. A study by Sukandar, Qowiyyah; Larasari (2013) demonstrated that the methanolic extracts of A. cordifolia leaves in doses of 50,100 and $200 \mathrm{mg} \mathrm{kg}^{-1}$ were able to decrease blood glucose in diabetic mice induced with alloxane. It was also observed that there was repair of damaged pancreatic $\beta$ at doses of 50 and $200 \mathrm{mg} \mathrm{kg}^{-1}$ (Sukandar; Qowiyyah; Larasari, 2013).

Djamil et al. (2017) isolated the compounds from an extract of ethyl acetate from the leaves of A. cordifolia, where the flavonoids 8-glucopyranosyl-4, 8-glucopyranosylapigenin and 8-glucosylapigenin were identified. The study evaluated the antidiabetic activity of these flavonoids in hyperglycemic rats induced by alloxane, where it was found that 8-glucosylapigenin, also known as orientoside, has an inhibitory activity by the enzyme $\alpha$-glucosidase and its ability to decrease blood glucose (Djamil et al., 2017).

\section{Cactaceae}

Opuntia ficus-indica (L.) Mill, palm-of-the-northeast, also known as foraging palm, is the cactus with the greatest potential for exploration in the Brazilian Northeast, representing an important forage resource in periods of drought, due to the presence of high levels of phytomass, in the semi-arid environmental conditions (Melo et al., 2003).

The palm is considered a food with a high water content, rich in non-fibrous carbohydrates, high ash content, although it has low levels of crude protein and neutral detergent fiber (Batista et al., 2003).

In the diet, the fruits and their peels are used in the preparation of juice, pulp, liqueurs, wines, sweets, jams, purees, jams, marmalades, liquid sweetener, edible seed oil, salads, cakes, yogurt and the stem used in salads sautéed and as a vegetable in various preparations. In traditional medicine, the palm is widely used to fight obesity, diabetes, gastrointestinal disorders and hyperlipidemia (Barbera, 2001).

Its chemical constituents vary according to age, time of year and forms of management, however the presence of phenolic compounds, several flavonoids and betalains are common (Slimen et al., 2017).

A study carried out in Mexico, found the use of this plant in 8 diabetic patients not dependent on insulin, where all used glibenclamide for the control of diabetes. The drug was discontinued three days before the experiment. It consisted of 6 women and 2 men aged 45 to 68 years, on the day of the test they drank juice from the stems and stem of $O$. ficus-indica through crude and grilled samples of the plant, after preparation, one of the samples was heated at $60{ }^{\circ} \mathrm{C}$ for 10 minutes (Frati; Jiménez; Ariza, 1990). 
Blood samples were collected at 0,30,60, 120 and 180 minutes after ingesting the juice of $O$. ficus-indica. The results showed that there was a significant decrease in serum glucose levels in 120 and 180 minutes, with no difference between raw or heated extracts (Frati; Jiménez; Ariza, 1990).

The mechanism of action of decreasing glucose by $O$. ficus-indica is still unknown, but the consumption of plant stems has the ability to decrease glucose levels in diabetic patients not dependent on insulin (Frati; Jiménez; Ariza, 1990).

Butterweck et al. (2011) carried out a comparative study of two different extracts of this plant in rats, whose basal glucose levels were increased, where an aqueous extract of the stems and another containing a mixture of stem and fruit peels were used. The results showed that $O$. ficus-indica extracts administered orally, are effective in reducing blood sugar levels.

However, there was an increase in the levels of basal insulin in the plasma, when the extract with stem and peel of the fruit was used. Thus, it is suggested that the active ingredients are not found only in the stems of $O$. ficus-indica. This result indicates that the constituents found in the shell material may have stimulatory effects on insulin secretion pathways and that this effect was not observed when only the aqueous extract of the stems was administered (Butterweck et al., 2011).

The same authors point out that current treatments for type 2 diabetes are aimed at increasing insulin secretion or sensitivity and, therefore, extracts of $O$. ficus-indica are a promising option for new drugs with an anti-diabetic effect (Butterweck et al., 2011).

\section{Caricaceae}

Carica papaya L., the popular papaya, is a typically tropical plant that has maximum diversity in Mexico and the Upper Amazon Basin, being grown in almost all Brazilian territory, especially in the states of Bahia, Espírito Santo and Ceará (Faria et al., 2009).

Some studies are being carried out to prove the hypoglycemic effects of $C$. papaya leaves. According to a study by Maniyar; Bhixavatimath (2012), in India, they used the aqueous extract of the leaves of $C$. papaya in diabetic rats induced by alloxane and the results showed the efficacy of the plant in the control of blood glucose levels and an improvement of the lipid profile in diabetic rats.

Juaréz-Rojop et al. (2014) carried out work with diabetic rats induced by streptozotocin and the animals were treated with chloroform extract from the leaves of C. papaya, orally, for 20 days. In the end, he observed that the plant extract significantly reversed the damage caused by diabetes, as papaya had a hypoglycemic and hypolipidemic effect, decreasing the concentration of serum triglycerides and total cholesterol in diabetic rats, having no impact on plasma insulin levels, suggesting that it does not stimulate insulin secretion (Juaréz-Rojop et al., 2014).

In the same work, the authors carried out the phytochemical identification of the compounds of C. papaya, with different extracts obtained. The presence of alkaloids, steroids, quinones and tannins in the ethanolic extract. In the hexane and chloroform extract, only steroids and 
quinones were observed; steroids in greater quantity in the chloroform extract (Juaréz-Rojop et al., 2014).

\section{Convolvulaceae}

Ipomoea carnea Jacq., known as wild cotton, widely used in ornamenting landscapes for the beauty of flowers, this species can be found in several regions of Brazil (Souza; Lorenzi, 2008).

Khan et al. (2014) carried out a phytochemical analysis of the aqueous and alcoholic extracts of I. carnea, where the presence of total levels of phenolic compounds, flavonoids and tannins was found, with the alcoholic extract having higher levels than the aqueous extract. The authors also evaluated the antidiabetic effects of these extracts in hyperglycemic rats induced by streptozotocin, verifying that I. carnea has hypoglycemic activity at doses of $500 \mathrm{mg} \mathrm{kg}^{-1}$, as it significantly decreases blood glucose levels, plasma triglycerides, total cholesterol, lipoprotein from low density (LDL) and increased the level of high density lipoprotein (HDL) compared to the control group rats (Khan et al., 2014).

Knowing that the reduction of diabetes and its associated complications can be achieved by inducing the body's antioxidant defense or reducing the production of free radicals, Khan et al. (2015) carried out another study where it also demonstrated that I. carnea extracts have the ability to improve stress biomarkers, since it was found that the reduced level of malondialdehyde and increased levels of superoxide dismutase, catalase, glutathione peroxidase and blood glutathione, were reversed by treatment with extracts of I. carnea, reducing the oxidative stress produced by diabetes (Khan et al., 2015).

\section{Lamiaceae}

Ocimum gratissimum L., is a herbaceous plant, found in savannas, tropical forests and coastal areas of West Africa and tropical Asia, in Nigeria it is commonly used as a condiment in cooking (Oguanobi; Chijioke; Ghasi, 2012). In Brazil it is popularly known as African Basil, Wild Basil or Clove Basil being sub-spontaneous throughout the Brazilian territory (Lorenzi; Matos, 2002).

Phytochemical analysis of the methanolic and aqueous extract of the leaves of $O$. gratissimum, detected the presence of several constituents such as tannins, steroids, flavonoid terpenoids and cardiac glycosides (Akinmoladun et al., 2007).

Several studies are found in the literature on the use of $O$. gratissimum in the treatment of diabetes. Okon et al. (2012) carried out a study in Nigeria, using diabetic rats induced by streptozotocin, where they were treated with aqueous extract of the leaves of the basil in the proportion of $1500 \mathrm{mg} \mathrm{mL}^{-1}$ for 28 days. At the end of the period, he observed that there was a decrease in blood glucose levels and that there was also a significant improvement in other common diabetes symptoms, such as polyphagia, polydipsia, polyuria and weight loss, suggesting that the $O$. gratissimum extract affects the neuroendocrine regulation of food intake by the gastrointestinal system, including the detection of nutrients and the secretion of peptides by enteroendocrine cells (Okon et al., 2012).

Another work, done by Oguanobi; Chijioke; Ghasi (2012), proved once again, the effects of the 
aqueous and alcoholic extracts of $O$. gratissimum in normal and diabetic rats induced, after the detection of blood glucose, there was a significant decrease in the glycemic levels of the animals that received the extracts. Since the aqueous extract produced a significantly greater degree of blood glucose reduction, compared to the alcoholic extract, suggesting that the active substances in the plant may be more soluble in water. The authors emphasize that there is a need to conduct controlled clinical trials to confirm the hypoglycemic effect in humans (Oguanobi; Chijioke; Ghasi, 2012).

\section{Malvaceae}

Abelmoschus esculentus (L.) Moench, or okra, is a vegetable, a fruit originally from Ethiopia that was introduced in Brazil by African slaves. It is widely used as a vegetable in food in regions of Northeastern Brazil, but little used in the rest of the country (Moura; Guimarães, 2014).

Although it is a vegetable, this species has in its property compounds that exert medicinal activity, for example, the presence of polysaccharides and micro emollients, which help in the functioning of the intestine, reduce stomach problems and can be used for the treatment of diarrhea (Adelakun et al., 2010). Okra seeds have a percentage of lectins in their composition, with a predominance of fibers, soluble carbohydrates, proteins and lipids (Soares, 2010).

Research is being carried out with this species to verify its action in the treatment of diabetes. Sabitha et al. (2011) conducted a study with the purpose of proving the hypoglycemic effects of A. esculentus in diabetic rats induced by streptozotocin, where they made oral use of a powder prepared from the bark and seeds of the plant, in a dose of 100 at $200 \mathrm{mg} \mathrm{kg}^{-1}$. A significant reduction in glucose levels were observed when compared to the control group with glibenclamide and there was also a normalization of the high lipid profile of the animals. These results suggest for the first time the potential of A. esculentus in the treatment of diabetes and demonstrate its hypoglycemic and hypolipidemic profile (Sabitha et al., 2011).

According to an in vitro study, conducted by Sabitha; Panneerselvam; Ramachandran (2012), okra bark and seed extracts have an important hypoglycemic effect, possibly explained by the inhibition of the enzymes $\alpha$-amylase and $\alpha$-glucosidase, and their inhibition would slow the absorption of carbohydrates, reducing blood glucose postprandial.

In another study, carried out in Brazil, the polar fraction of A. esculentus extract ("okra water") was used in diabetic mice and the glucose levels decreased by approximately $35 \%$, this decrease occurred approximately 4.5 fold higher compared to the control group (Dos Santos; Costa; Santos, 2014). The "okra water" obtained after placing the sliced fruits in water and subsequent filtration provides a large amount of soluble fibers, which may be the cause of the decrease in glucose, due to the interaction between fibers and nutrients consumed (Dos Santos; Costa; Santos, 2014).

\section{Musaceae}

Musa paradisiaca L., the banana is one of the most consumed fruits in the world, being produced in most tropical countries and cultivated in all Brazilian states, from the coast to the 
interior plateaus (Borges et al., 2006).

In order to evaluate the hypoglycemic activity of $M$. paradisiaca, Usha; Vijayammal; Kurup (1989), isolated the fibers of the banana fruit, administered it to rats and subsequently verified lower glucose levels in fasting animals.

The pulp of the fruit has important compounds, of great nutritional value, besides being responsible for the biological activities of this species. They are serotonin, norepinephrine, tryptophan, indole compounds, tannin, starch, iron, crystallizable and non-crystallizable sugars, vitamin C, B vitamins, albuminoids, fats and minerals (Imam; Akter, 2011).

Mallick et al. (2007) carried out a study using the aqueous methanolic extract of the root of $M$. paradisiaca in diabetic rats induced by streptozotocin, where there was a significant repairing effect on glucose levels, on the amount of metabolic carbohydrate enzymes, on the presence of glycogen in the liver and in the skeletal muscles, and significant recovery of insulin levels (Mallick et al., 2007). The authors carried out in the same study an administration composed of the extract of $M$. paradisiaca and Coccinia indica, where the effects already reported were even more potent (Mallick et al., 2007).

\section{Myrtaceae}

Psidium cattleyanum Sabine, known as araçá, is originally from southern Brazil, its cultivation is spread from Rio Grande do Sul to Bahia, among other South American countries (Brandão; Laca-Buendia; Macedo, 2002). It is among the most exploited native fruits for its bioactive components with antioxidant potential (Pereira, 2018). The phytochemical analysis of the araçá crude ethanolic extract revealed the presence of compounds such as catechins, steroids, phenolic compounds, flavonoids and saponins (Faleiro et al., 2016).

Pacheco (2015) demonstrated in his study that methanolic extracts of $P$. cattleyanum are effective in inhibiting the enzymes $\alpha$-amylase and $\alpha$-glycosidase in vitro and can be a promising candidate in the management of postprandial hyperglycemia. In a more recent study carried out in Brazil, diabetic rats resistant to insulin induced by dexamethasone were used, where they were treated with extract of $P$. cattleyanum at a dose of $200 \mathrm{mg} \mathrm{kg}^{-1} \mathrm{day}^{-1}$ for a period of 21 days, demonstrating at the end of the study. The experiment that araçá has an important effect in reducing hyperglycemia and hypertriglyceridemia (De Souza Cardoso, 2018).

Syzygium cumini (L.) Skeels, a fruit known to the population as Java Plum or Black Plum is originally from Indo Malaysia, China and the Antilles, being grown in Brazil and other countries (Lorenzi et al., 2006). Shells and seeds are often used in the Far East to treat hyperglycemia and glycosuria in diabetic patients (Chaudhary; Mukhopadhyay, 2012).

In phytochemical analysis of the compounds of S. cumini, it was observed the presence of chemical constituents considered active medicinal such as, alkaloids, glycosides, triterpenoids, steroids, saponins, flavonoids and tannins (Kamal, 2014).

A study by Kumar et al. (2013) a compound called mycaminosis was isolated from the seed of S. cumini in order to observe its action against streptozotocin in diabetic rats. There was a 
significant reduction in glycemic levels compared to the standard drug glibenclamide, proving its hypoglycemic action.

Alam et al. (2012) carried out a work in order to identify the possible constituents of antidiabetic activity, in which four substances were isolated, among them lupeol and stigmasterol stand out, substances with an important hypoglycemic effect, proving the effectiveness of $S$. cumini in the treatment of diabetes.

\section{Nyctaginaceae}

Bougainvillea glabra Choisy, is a woody shrub, native to the south of Brazil, presents flowers of pink or almost lilac color, popularly known as Paper Flower, a species widely used in garden ornamentation (Lorenzi; Souza, 1999).

The Paper Flower is a plant traditionally used in the treatment of diabetes, in this sense, Adebayo et al. (2009) described the antidiabetic action of aqueous leaf extract, of this species, in diabetic rats induced by alloxane, justifying its traditional use. Another study, with the aqueous extract of the leaves of B. glabra, carried out by Soni et al. (2013) showed efficacy in wound healing in diabetic rats. This extract can also be used in procedures for tissue regeneration, especially in diabetic patients who have wounds that are difficult to heal.

A study by Saleem et al. (2019), identified the phytochemical constituents of the extract of the aerial parts of $B$. glabra with methanol. The phytochemical profile of the methanolic extract showed a total of 20 chemical constituents and the main ones were flavonoids, phenolic compounds and alkaloids. The authors also found a potent antioxidant action and significant cytotoxic action in vitro against cancer cells. Thus, this species contains important compounds for the development of pharmaceutical formulations, cosmetic applications or its use as a food supplement.

Bougainvillea spectabilis Willd, known for Great Bougainvillea, is a woody shrub native to eastern and northeastern Brazil. Its flowers are very showy, they can appear folded or open, colored wine, orange, rust, white and pink, formed in autumn-spring. In addition, its flowers are widely used to embellish landscapes and gardens (Lorenzi; Souza, 1999).

Phytochemical analysis of ethanolic extracts from the stem bark of B. spectabilis showed the presence of several compounds, such as flavonoids, glycosides, tannins and saponins (Jawla; Kumar; Khan, 2013). In addition, this extract showed potent hypoglycemic activity in diabetic rats (Jawla; Kumar; Khan, 2012).

The aqueous extract of $B$. spectabilis leaves at a dose of $100 \mathrm{mg} \mathrm{kg}^{-1}$ significantly reduced the blood glucose level of diabetic rats. The possible mechanism of action of the leaf extract may be correlated to the presence of the compound D-pinitol. The extract of the leaves significantly restored the levels of creatinine and uric acid very close to the normal level and the urea level was not altered, nor were histological changes observed (Chauhan et al., 2016). In another study, carried out by Bhat et al. (2011), also with the aqueous extract of spring leaves, in a diabetes model, there was protection and regeneration of the pancreatic islets, without causing toxicity. Thus, showing that this species can be an important option in the treatment of diabetes. 
The compound D-pinitol, isolated from spring leaves, clearly showed the anti-hyperlipidemic and anti-diabetic effect in animal models. The levels of glucose, total cholesterol, triglycerides, free fatty acids and phospholipids in serum, liver, kidney, heart and brain decreased. D-pinitol also significantly reduced LDL and VLDL cholesterol levels and significantly increased HDL cholesterol levels in diabetic rats (Geethan; Prince, 2008).

\section{Phyllantaceae}

Phyllanthus niruri L., popularly known in Brazil as stonebreaker, is a ruderal herb that occurs in almost all the tropical region until the south of North America, common in cracks in sidewalks, vacant lots, backyards and gardens throughout the territory Brazilian (Lorenzi; Matos, 2002).

It is widely known by the population for its diuretic effect (Silva, 2004). However, some studies have been carried out to prove the hypoglycemic effects of P. niruri. A study, conducted in India by Mazunder; Gupta; Rajeshwar (2005) used diabetic rats, induced by streptozotocin, treated with methanolic extract of $P$. niruri, in the proportion of $125 \mathrm{mg} \mathrm{kg}^{-1}$ and $250 \mathrm{mg} \mathrm{kg}^{-1}$, to evaluate its hypoglycemic and antioxidant effect. At the end of 14 days of treatment with the extract, a significant reduction in the glucose in the blood of the animals was observed, proving the reduction in glucose levels and also the antioxidant action, suggesting that $P$. niruri, may be effective in reducing oxidative stress and of diseases related to free radicals, including diabetes (Mazunder; Gupta; Rajeshwar, 2005).

Okoli et al. (2010) carried out an experiment with diabetic rats induced by alloxane, treated with methanolic extract of the plant and observed a reduction in the levels of glucose, total cholesterol and triglycerides in normal and diabetic rats. The results also showed that $P$. niruri extract suppressed the postprandial increase in glycemia in normal rats, after a heavy glucose meal, and that, if added to the hypoglycemic and hypolipidemic effect, this species can reduce complications caused by diabetes (Okoli et al., 2010).

A phytochemical study, carried out with the crude extract of the stonebreaker, showed the presence of steroids, triterpenoids, alkaloids, depsides, depsidones, reducing sugars and anthraquinones (Do Rosário, 2016).

\section{Solanaceae}

Capsicum baccatum var. pendulum (Willd) Eshbaugh, widely cultivated in Brazil, with origins in the Americas and that today is consumed all over the world, mainly as condiments it is popularly known as pepper-cambuci or black-hat, and that due to its little pungency it is considered as sweet pepper. Pungency, common in peppers, is due to the presence of alkaloids and two important capsaicinoids, capsaicin and dihydrocapsaicin, (Carvalho et al., 2006).

Capsaicin is being studied for its pharmacological activities, a study by Yuan et al. (2016) carried out with pregnant women, diagnosed with gestational diabetes mellitus, where they included $5 \mathrm{mg}$ of capsaicin per day in their diets for 4 weeks, it was observed at the end of the period that there was improvement in postprandial hyperglycemia and hyperinsulinemia, suggesting that capsaicin was beneficial in postprandial glucose metabolism (Yuan et al., 
2016).

\section{Zingiberaceae}

Zingiber officinale Roscoe, popularly known as ginger, has its origin in Asia and is grown in Brazil. It is characterized by having its rhizomes of smell and pungent flavor, widely used in food as a condiment and raw material for food manufacturing (Lorenzi; Matos, 2002). Since antiquity, ginger has been used as alternative medicine by countries like India, Japan, China, Greece, Rome and the Mediterranean (Baliga et al., 2011).

Ginger is used for several therapeutic purposes, has antimicrobial, anti-inflammatory, antipyretic, diuretic, antioxidant, hepatoprotective action, in the reduction and control of blood glucose and cholesterol. These biological activities occur due to the presence of bioactive compounds, mainly sesquitespene hydrocarbons, such as zingiberene, curcumin and farnesene, other constituents such as gingerols, soagols, paradols and zingerone are found in rhizomes (Nicácio et al., 2018).

Jolad et al. (2005) isolated the Z. officinale compounds in fresh samples and dry extract of the rhizomes of this plant, where a total of 115 different compounds were found, with gingerol being the main bioactive component of the species. Al-Amin et al. (2006) proved in his study the hypoglycemic activity of ginger using diabetic rats induced by streptozotocin, where they were treated for 7 weeks with aqueous extract of raw Z. officinale, in the proportion of 500 $\mathrm{mg} \mathrm{kg}^{-1}$. At the end of this period, it was observed that there was a reduction in serum glucose levels, total cholesterol, triglycerides and also, a reduction in protein levels in the urine, reversing diabetic proteinuria (Al-Amin et al., 2006).

The reduction in blood glucose may be due to effects involving serotonin receptors increased pancreatic insulin secretion or release of bound insulin, thus being able to be used to control diabetic complications in humans (Al-Amin et al., 2006).

In Brazil, in a recent study by Carvalho (2018), a group of 103 diabetic patients used dry ginger extract in capsules at a dose of $600 \mathrm{mg}$ twice a day, for 90 days, where at the end of the study, it is known that $Z$. officinale significantly decreased fasting glycemia, cholesterol and LDL cholesterol, and can be considered a supporting alternative in the treatment of diabetes mellitus (Carvalho, 2018).

\section{Conclusion}

It is concluded that, in a general analysis, all 18 species presented have hypoglycemic potential proven with several studies, however, it is necessary that there are more pre-clinical and clinical studies in line with government technical standards, which ensure that these plants can be used effectively and safely by the population. The data of this work also collaborate for new research to be carried out with these species, so that in the future, they can integrate the pharmaceutical market in the form of herbal medicine, to be used exclusively or as an adjuvant in the treatment of diabetes mellitus and its complications.

\section{Conflict of interest}


The authors declare that there are no conflicts of interest in this study.

\section{References}

Adebayo, G. I., Alabi, O. T., Owoyele, B. V., \& Soladoye, A. O. (2009). Anti-diabetic properties of the aqueous leaf extract of Bougainvillea glabra (Glory of the Garden) on alloxan-induced diabetic rats. Records of Natural Products, 3(4), 187-192.

Adelakun, O. E., Ade-Omowaye, B. I. O., Adeyemi, I. A., \& Venter, M. (2010). Functional properties and mineral contents of a Nigerian okra seed (Abelmoschus esculentus Moench) flour as influenced by pretreatments. Journal of Food Technology, 8(2), 39-45.

Akinmoladun, A. C., Ibukun, E. O., Afor, E., Obuotor, E. M., \& Farombi, E. O. (2007). Phytochemical constituent and antioxidant activity of extract from the leaves of Ocimum gratissimum. Scientific Research and Essays, 2(5), 163-166. https://doi.org/10.5897/SRE2019.6660

Alam, M. R., Rahman, A. B., Moniruzzaman, M., Kadir, M. F., Haque, M. A., Alvi, M. R. U. H., \& Ratan, M. D. (2012). Evaluation of antidiabetic phytochemicals in Syzygium cumini (L.) Skeels (Family: Myrtaceae). Journal of applied pharmaceutical science, 2(10), 94-98.

Al-Amin, Z. M. et al. (2006). Anti-diabetic and hypolipidaemic properties of ginger (Zingiber officinale) in streptozotocin-induced diabetic rats. British journal of nutrition, 96(4), 660-666. https://doi.org/10.1079/BJN20061849

Almourani, R., Chinnakotla, B., Patel, R., Kurukulasuriya, L. R., \& Sowers, J. (2019). Diabetes and cardiovascular disease: an update. Current diabetes reports, 19(12), 161. https://doi.org/10.1007/s11892-019-1239-x

Baliga, M. S., Haniadka, R., Pereira, M. M., D’Souza, J. J., Pallaty, P. L., Bhat, H. P., \& Popuri, S. (2011). Update on the chemopreventive effects of ginger and its phytochemicals. Critical reviews in food science and nutrition, 51(6), 499-523. https://doi.org/10.1080/10408391003698669

Barbera, G. (2001). História e importância econômica e agroecológica. In: Barbera, G.; Inglese, P.; Pimienta-Barrios, E. Agroecologia, cultivo e usos da palma forrageira. (pp.1-11). $\mathrm{FAO} /$ Sebrae.

Batista, A. M. V., Mustafa, A. F., Santos, G. R. A., De Carvalho, F. F. R., B. Dubeux Jr, J. C., Lira, M. A., \& Barbosa, S. B. P. (2003). Chemical composition and ruminal dry matter and crude protein degradability of spineless cactus. Journal of Agronomy and crop Science, 189(2), 123-126. https://doi.org/10.1046/j.1439-037X.2003.00008.x

Bhat, M., Kothiwale, S. K., Tirmale, A. R., Bhargava, S. Y., \& Joshi, B. N. (2011). Antidiabetic properties of Azardiracta indica and Bougainvillea spectabilis: in vivo studies in murine diabetes model. Evidence-Based Complementary and Alternative Medicine. https://doi.org/10.1093/ecam/nep033

Borges, A. L., Oliveira, A. M. G., Ritzinger, C. H. S. P., de ALMEIDA, C. O., Coelho, E. F., 
SEREJO, J. D. S., ... \& Meissner Filho, P. E. (2006). A cultura da banana. Brasília, DF: Embrapa Informação Tecnológica, 2006.

Brandão, H. N., David, J. P., Couto, R. D., Nascimento, J. A., \& David, J. M. (2010). Química e farmacologia de quimioterápicos antineoplásicos derivados de plantas. Química nova, 33(6), 1359-1369. https://doi.org/10.1590/S0100-40422010000600026

Brandão, M., Laca-Buendía, J. P., \& Macedo, J. F. (2002). Árvores nativas e exóticas do Estado de Minas Gerais (528 p). Belo Horizonte: EPAMIG.

Brasil. Ministério da Saúde (2006). Política Nacional de práticas integrativas e complementares no SUS. Ministério da Saúde: Brasília. Available in: https://www.saude.gov.br/bvs

Brasil. Ministério da Saúde (2016). Política e Programa Nacional de Plantas Medicinais e Fitoterápicos. Ministério da Saúde: Brasília. Available in: https://www.saude.gov.br/bvs

Butterweck, V., Semlin, L., Feistel, B., Pischel, I., Bauer, K., \& Verspohl, E. J. (2011). Comparative evaluation of two different Opuntia ficus-indica extracts for blood sugar lowering effects in rats. Phytotherapy Research, 25(3), 370-375. https://doi.org/10.1002/ptr.3271

Canzi, K. N., Byczkovski, C., Grigol, D. É. B., Canezin, M., de Lima, L. T., Corrêa, É. J. T., ... \& Takemura, O. S. (2012). Levantamento florístico do horto medicinal do campus 2 da Universidade Paranaense (UNIPAR) Umuarama/Pr. Arquivos de Ciências da Saúde da UNIPAR, 16(3). https://doi.org/10.25110/arqsaude.v16i3.2012.4967

Carvalho, G. C. N. (2018). Efeito do gengibre (Zingiber officinale) no controle glicêmico e lipêmico de pessoas com diabetes tipo 2: ensaio clínico randomizado duplo cego controlado por placebo (Doutorado em Enfermagem). Faculdade de Farmácia, Odontologia e Enfermagem, Universidade Federal do Ceará, Fortaleza.

Cavalcanti, M. L. F., Dantas, I. C., Costa, G. M. C. S., Barros, M. J. B., \& Lira, R. S. (2004). Identificação dos vegetais destinados à ornamentação de praças, parques e creches em Campina Grande, PB. Revista de Biologia e Ciências da Terra, 4(1). 1-21.

Cavalli, V. L. D. L. O., Sordi, C., Tonini, K., Grando, A., Muneron, T., Guigi, A., \& Roman Júnior, W. A. (2007). Avaliação in vivo do efeito hipoglicemiante de extratos obtidos da raiz e folha de bardana Arctium minus (Hill.) Bernh. Revista Brasileira de Farmacognosia, 17(1), 64-70. http://dx.doi.org/10.1590/S0102-695X2007000100014

Chaudhary, B., \& Mukhopadhyay, K. (2012). Syzygium cumini (L.) Skeels: Uma fonte potencial de nutracêuticos. International Journal of Pharmacy Biological Sciences, 2(1), 46-53.

Chauhan, P., Mahajan, S., Kulshrestha, A., Shrivastava, S., Sharma, B., Goswamy, H. M., \& Prasad, G. B. K. S. (2016). Bougainvillea spectabilis exhibits antihyperglycemic and antioxidant activities in experimental diabetes. Journal of Evidence-Based Complementary \& Alternative Medicine, 21(3), 177-185. https://doi.org/10.1177/2156587215595152 
De Carvalho, S. I. C., Bianchetti, L. D. B., Ribeiro, C. D. C., \& Lopes, C. A. (2006). Pimentas do gênero Capsicum no Brasil. Embrapa Hortaliças-Documentos (INFOTECA-E).

De Souza Cardoso, J., Oliveira, P. S., Bona, N. P., Vasconcellos, F. A., Baldissarelli, J., Vizzotto, M., ... \& Tavares, R. G. (2018). Antioxidant, antihyperglycemic, and antidyslipidemic effects of Brazilian-native fruit extracts in an animal model of insulin resistance. Redox report, 23(1), 41-46. https://doi.org/10.1080/13510002.2017.1375709

Djamil, R., Winarti, W., Zaidan, S., \& Abdillah, S. (2017). Antidiabetic activity of flavonoid from binahong leaves (Anredera cordifolia) extract in alloxan induced mice. Journal Pharmacognosy Natural Products, 3(02), 139. https://doi.org/10.4172/2472-0992.1000139

Do Rosário, A. C. D. A. (2016). Análise fitoquímica da espécie Phyllanthus niruri L. (quebra-pedra). Estação Científica $\quad$ (UNIFAP), $\quad 6(1), \quad 35-41$. http://doi.org/10.18468/estcien.2016v6n1.p35-41

Dos Santos, A. V., Costa, E. S., \& Santos, M. (2014). Efeito dos compostos solúveis em água de quiabo (Abelmoschus esculentus L) nos níveis glicêmicos de camundongos Mus musculus. Ciência et Praxis, 7(13), 07-10. Available in: http://revista.uemg.br/index.php/praxys/article/view/2132/1124

Faleiro, J. H., Gonçalves, R. C., Dos Santos, M. N. G., Da Silva, D. P., Naves, P. L. F., \& Malafaia, G. (2016). The chemical featuring, toxicity, and antimicrobial activity of Psidium cattleianum (Myrtaceae) leaves. New Journal of Science. https://doi.org/10.1155/2016/7538613

Faludi, A. A., Izar, M. C. D. O., Saraiva, J. F. K., Bianco, H. T., Chacra, A. P. M., Bertoluci, M. C., ... \& Schaan, B. D. (2017). Diretriz brasileira baseada em evidências sobre prevenção de doenças cardiovasculares em pacientes com diabetes: posicionamento da Sociedade Brasileira de Diabetes (SBD), da Sociedade Brasileira de Cardiologia (SBC) e da Sociedade Brasileira de Endocrinologia e Metabologia (SBEM). Arquivos Brasileiros de Cardiologia, 109(6), 1-31.

Faria, A. R. N., Noronha, A. D. S., Oliveira, A. A. R., Oliveira, A. M. G., Cardoso, C. E. L., Ritzinger, C. H. S. P., ... \& Oliveira, J. D. (2009). A cultura do mamão. Brasília, DF: Embrapa Informação Tecnológica; Cruz das Almas: Embrapa Mandioca e Fruticultura Tropical, 2009.

Feijó, A. M., Bueno, M. E. N., Ceolin, T., Linck, C. L., Schwartz, E., Lange, C., ... \& Heiden, G. (2012). Plantas medicinais utilizadas por idosos com diagnóstico de Diabetes mellitus no tratamento dos sintomas da doença. Revista Brasileira de Plantas Medicinais, 14(1), 50-56. https://doi.org/10.1590/S1516-05722012000100008

Frati, A. C., Jiménez, E., \& Ariza, C. R. (1990). Hypoglycemic effect of Opuntia ficus indica in non insulin-dependent diabetes mellitus patients. Phytotherapy research, 4(5), 195-197. https://doi.org/10.1002/ptr.2650040507

Garber, A. J., Abrahamson, M. J., Barzilay, J. I., Blonde, L., Bloomgarden, Z. T., Bush, M. A., ... \& Garber, J. R. (2019). Consensus statement by the American Association of Clinical Endocrinologists and American College of Endocrinology on the comprehensive type 2 
diabetes management algorithm-2019 executive summary. Endocrine Practice, 25(1), 69-100.

Geethan, P. A., \& Prince, P. S. M. (2008). Antihyperlipidemic effect of D-pinitol on streptozotocin-induced diabetic wistar rats. Journal of biochemical and molecular toxicology, 22(4), 220-224. https://doi.org/10.1002/jbt.20218

Heidarian, E., \& Soofiniya, Y. (2011). Hypolipidemic and hypoglycemic effects of aerial part of Cynara scolymus in streptozotocin-induced diabetic rats. Journal of medicinal plants research, 5(13), 2717-2723.

Imam, M. Z., \& Akter, S. (2011). Musa paradisiaca L. and Musa sapientum L.: A phytochemical and pharmacological review. Journal of Applied Pharmaceutical Science, 1(5), 14-20.

Jawla, S., Kumar, Y., \& Khan, M. S. Y. (2012). Hypoglycemic activity of Bougainvillea spectabilis stem bark in normal and alloxan-induced diabetic rats. Asian pacific journal of Tropical Biomedicine, 2(2), S919-S923. https://doi.org/10.1016/S2221-1691(12)60337-2

Jawla, S., Kumar, Y., \& Khan, M. S. Y. (2013). Isolation of antidiabetic principle from Bougainvillea spectabilis willd (Nyctaginaceae) stem bark. Tropical Journal of Pharmaceutical Research, 12(5), 761-765. https://10.4314/tjpr.v12i5.15

Jolad, S. D., Lantz, R. C., Chen, G. J., Bates, R. B., \& Timmermann, B. N. (2005). Commercially processed dry ginger (Zingiber officinale): composition and effects on LPS-stimulated PGE2 production. Phytochemistry, 66(13), 1614-1635. https://doi.org/10.1016/j.phytochem.2005.05.007

Juárez-Rojop, I. E., Tovilla-Zárate, C. A., Aguilar-Domínguez, D. E., Roa-de la Fuente, L. F., Lobato-García, C. E., Blé-Castillo, J. L., ... \& Bermúdez-Ocaña, D. Y. (2014). Phytochemical screening and hypoglycemic activity of Carica papaya leaf in streptozotocin-induced diabetic rats. Revista Brasileira de Farmacognosia, 24(3), 341-347. https://doi.org/10.1016/j.bjp.2014.07.012

Kamal, A. (2014). Phytochemical screening of Syzygium cumini seeds. Indian Journal of Plant Sciences, 3(4), 1-4. Available in: http://www.cibtech.org/jps.htm

Khan, T. Y., Raina, R., Verma, P. K., Sultana, M., \& Mahrukh, A. (2015). Protective effect of Ipomoea carnea Jacq leaves extracts on streptozotocin-induced oxidative stress in rats. J Exp Integr Med, 5(1), 1.

Khan, Y. T., Raina, R., Verma, K. P., Sultana, M., \& Jyoti, K. M. (2014). Phytochemical constituents and antidiabetic potential of Ipomoea carnea Jacq leaves extracts. Journal Experimental Interative Medicine, 4, 137-142. https://doi.org/10.5455/jeim.210214.or.096

Kinupp, V. F., Amaro, F. S., \& Barros, I. B. I. (2004). Anredera cordifolia (Basellaceae), uma hortaliça potencial em desuso no Brasil. Horticultura Brasileira, 22(2), 346-356

Kumar, A., Ilavarasan, R., Jayach, T., Deecaraman, M., Aravindan, P., Padmanabhan, N., \& 
Krishan, M. R. V. (2013). Anti-diabetic activity of Syzygium cumini and its isolated compound against streptozotocin-induced diabetic rats. Journal of Medicinal Plants Research, 2(9), 246-249.

Kumar, P., Sujatha, D., Mohamed, S. T. S., Madhusudhana, C. C., \& Ranganayakulu, D. (2010). Potential hypoglycemic \& hypolipidemic effect of Morus Indica and Asystasia gangetica in alloxan induced diabetes mellitus. International Journal of Research in Pharmaceutical Sciences, 1(2). Retrieved from https://pharmascope.org/ijrps/article/view/142

Lorenzi, H., \& Matos, F. J. A. (2002). Plantas medicinais do Brasil: nativas e exóticas. Nova Odessa: Instituto Plantarum de Estudos da Flora. p. 502.

Lorenzi, H., \& Souza, H. M. (1999). Plantas Ornamentais no Brasil - Arbustivas, herbáceas e trepadeiras. (2 Edição). Nova Odessa: Instituto Plantarum de Estudos da Flora. p 1088.

Lorenzi, H., Bacher, L., Lacerda, M., \& Sartori, S. (2006). Frutas brasileiras e exóticas cultivadas (de consumo in natura). São Paulo: Instituto Plantarum de Estudos da Flora, p. 640.

Mallick, C., Chatterjee, K., GuhaBiswas, M., \& Ghosh, D. (2007). Antihyperglycemic Effects of separate and composite extract of root of Musa paradisiaca and leaf of Coccinia indica in streptozotocin-induced diabetic male albino rat. African Journal of Traditional, Complementary and Alternative Medicines, 4(3), 362-371.

Maniyar, Y., \& Bhixavatimath, P. (2012). Antihyperglycemic and hypolipidemic activities of aqueous extract of Carica papaya Linn. leaves in alloxan-induced diabetic rats. Journal of Ayurveda and integrative medicine, 3(2), 70. https://doi.org/10.4103/0975-9476.96519

Martins, A. V. V., Ferreira, L. V., Frauches, A. P., Nunes, L. C., Martins, C., \& Costa, M. B. (2019). Progressão de pré-diabetes para diabetes mellitus: um estudo de vida real. Revista Ciência em Extensão, 15(1), 50-58.

Mazunder, U. K., Gupta, M., Rajeshwar, Y. (2005). Antihyperglycemic effect and antioxidant potential of Phyllanthus niruri (Euphorbiaceae) in streptozotocin induced diabetic rats. European Bulletin Drug Research, 13(1), 15-23.

Melo, A. A. S. D., Ferreira, M. D. A., Verás, A. S. C., Lira, M. D. A., Lima, L. E. D., Vilela, M. D. S., ... \& Araújo, P. R. B. (2003). Substituição parcial do farelo de soja por uréia e palma forrageira (Opuntia fícus-indica Mill) em dietas para vacas em lactação: I. Desempenho. $\begin{array}{llll}\text { Revista Brasileira } & \text { 7e } & \text { Zootecnia, } & 32(3),\end{array}$ https://doi.org/10.1590/S1516-35982003000300025

Moura, A. P., Guimarães, J. A. (2014). Manejo de pragas na cultura do quiabeiro. Brasília: Embrapa Hortaliças. (Circular Técnica, 138). Available in: https://www.embrapa.br Acesso em: 20 jun. 2020.

Nammi, S., Boini, M. K., Lodagala, S. D., \& Behara, R. B. S. (2003). The juice of fresh leaves of Catharanthus roseus Linn. reduces blood glucose in normal and alloxan diabetic rabbits. BMC complementary and Alternative Medicine, 3(1), 4. https://doi.org/10.1186/1472-6882-3-4 
Nicácio, G. L., Moura, S., Costa, J. V. D. J., Sena, C. R., Cruz, T. B., Lopes, G. N., \& Cecilio, A. B. (2018). Breve revisão sobre as propriedades fitoterápicas do Zingiber officinale o gengibre. Sinapse Múltipla, 7(2), 74-80. Available in: http://periodicos.pucminas.br/index.php/sinapsemultipla

Nicoletti, M. A., Oliveira-Júnior, M. A., Bertasso, C. C., Caporossi, P. Y., \& Tavares, A. P. L. (2007). Principais interações no uso de medicamentos fitoterápicos. Infarma, 19(1/2), 32-40.

Noldin, V. F., Cechinel Filho, V., Monache, F. D., Benassi, J. C., Christmann, I. L., Pedrosa, R. C., \& Yunes, R. A. (2003). Composição química e atividades biológicas das folhas de Cynara scolymus L. (alcachofra) cultivada no Brasil. Química nova, 26(3), 331-334. https://doi.org/10.1590/S0100-40422003000300008

Oguanobi, N. I., Chijioke, C. P., \& Ghasi, S. I. (2012). Efeito antidiabético de extratos brutos de folhas de Ocimum gratissimum em ratos diabéticos modelo 2 induzidos por estreptozotocina neonatal. International Journal of Pharmacy and Pharmaceutical Science, 4(5), 77-83.

Oguanobi, N. I., Chijioke, C. P., \& Ghasi, S. I. (2012). Effects of aqueous leaf extract of Ocimum gratissimum on oral glucose tolerance test in type-2 model diabetic rats. African Journal of Pharmacy and Pharmacology, 6(9), 630-635. https://doi.org/10.5897/AJPP11.811

Okoli, C. O., Ibiam, A. F., Ezike, A. C., Akah, P. A., \& Okoye, T. C. (2010). Evaluation of antidiabetic potentials of Phyllanthus niruri in alloxan diabetic rats. African Journal of Biotechnology, 9(2), 248-259.

Okon, U. A., Owo, D. U., Udokang, N. E., Udobang, J. A., \& Ekpenyong, C. E. (2012). Oral administration of aqueous leaf extract of Ocimum gratissimum ameliorates polyphagia, polydipsia and weight loss in streptozotocin-induced diabetic rats. American Journal of Medicine and Medical Sciences, 2(3), 45-49. https://doi.org/10.5923/j.ajmms.20120203.04

Pacheco, S. M. (2015). Frutos da família Myrtaceae: Caracterização físicoquímica e potencial inibitório da atividade das enzimas digestivas (Dissertação em Ciência e Tecnologia de Alimentos). Universidade Federal de Pelotas.

Pereira, E. S. (2018). Caracterização de frutos de araçá (Psidium cattleianum Sabine): composição fenólica, atividade antioxidante e inibição de alfa-amilase e alfa-glicosidase (Dissertação em Ciência de Tecnologia de Alimentos). Universidade Federal de Pelotas.

Portis, E., Mauromicale, G., Barchi, L., Mauro, R., \& Lanteri, S. (2005). Population structure and genetic variation in autochthonous globe artichoke germplasm from Sicily Island. Plant Science, 168(6), 1591-1598. https://doi.org/10.1016/j.plantsci.2005.02.009

Sabitha, V., Panneerselvam, K., \& Ramachandran, S. (2012). Efeitos inibitórios da enzima $\alpha$-glucosidase e $\alpha$-amilase em extratos aquosos de Abelmoscus esculentus (L.) Moench. Revista do Pacífico Asiático de biomedicina tropical, 2(1), S162-S164. https://doi.org/10.1016/S2221-1691(12)60150-6

Sabitha, V., Ramachandran, S., Naveen, KR e Panneerselvam, K. (2011). Potencial antidiabético e anti-hiperlipidêmico de Abelmoschus esculentus (L.) Moench. em ratos 
diabéticos induzidos por estreptozotocina. Jornal de farmácia e ciências bioallied, 3(3), 397.

Saleem, H., Zengin, G., Ahmad, I., Lee, J. T. B., Htar, T. T., Mahomoodally, F. M., ... \& Ahemad, N. (2019). Multidirectional insights into the biochemical and toxicological properties of Bougainvillea glabra (Choisy.) aerial parts: A functional approach for bioactive compounds. Journal of pharmaceutical and biomedical analysis, 170, 132-138. https://doi.org/10.1016/j.jpba.2019.03.027

Salem, M. B., Kolsi, R. B. A., Dhouibi, R., Ksouda, K., Charfi, S., Yaich, M., ... \& Affes, H. (2017). Protective effects of Cynara scolymus leaves extract on metabolic disorders and oxidative stress in alloxan-diabetic rats. BMC complementary and alternative medicine, 17(1), 328. https://doi.org/10.1186/s12906-017-1835-8

Sales, M. D. C., Sartor, E. B., \& Gentilli, R. M. L. (2015). Etnobotânica e etnofarmacologia: medicina tradicional e bioprospecção de fitoterápicos. Salus Journal of Health Science, 1(1), 17-26. https://doi.org/10.5935/2447-7826.20150003

Silva, F. N. G. M. (2004). Plantas indicadas como diuréticas no Brasil desde Martius, 1843 (Dissertação em Fisiologia). Universidade Federal de Pernambuco, Recife.

Slimen, I. B., Mabrouk, M., Hanène, C., Najar, T., \& Abderrabba, M. (2017). LC-MS analysis of phenolic acids, flavonoids and betanin from spineless Opuntia ficus-indica fruits. Cell Biology, 5, 17-28. https://doi.org/10.11648/j.cb.20170502.12

Soares, G. D. S. F. (2010). Estudo da Qualidade Nutricional de Sementes e da Atividade Antiinflamatória da Lectina do Abelmoschus esculentus (L.) Moench (quiabo) (Mestrado em Ciências da Nutrição). Universidade Federal da Paraíba, João Pessoa.

Sociedade brasileira de diabetes (2020). Notas de esclarecimentos da Sociedade Brasileira de Diabetes sobre o coronavírus (COVID-19). Available in: https://www.diabetes.org.br/covid-19.Accessed on May 16, 2020.

Soni, R., Mehta, N. M., Trivedi, R., \& Srivastava, D. N. (2013). Effect aqueous extract of Bougainvillea glabra choisy on Cutaneous Wound healing in Diabetic Rats. Asian Journal of Complementary and Alternative Medicine, 1(01), 12-15.

Souza, V. C., \& Lorenzi, H. (2008). Botânica Sistemática: guia ilustrado para identificação das famílias brasileiras de fanerógamas nativas e exóticas no Brasil, baseado em APG II. (2a ed.) Instituto Plantarum, Nova Odessa. p. 703.

Sukandar, E. Y., Qowiyyah, A., \& Larasari, L. (2013). Effect of methanol extract hearhleaf madeiravine (Anredera cordifolia (Ten.) Steenis) leaves on blood sugar in diabetes mellitus model mice. Jurnal Medika Planta, 1(4).

Tabák, A. G., Herder, C., Rathmann, W., Brunner, E. J., \& Kivimäki, M. (2012). Prediabetes: a high-risk state for diabetes development. The Lancet, 379(9833), 2279-2290. https://doi.org/10.1016/S0140-6736(12)60283-9

Tavares, N. U. L., Bertoldi, A. D., Mengue, S. S., Arrais, P. S. D., Luiza, V. L., Oliveira, M. 
A., ... \& Pizzol, T. D. S. D. (2016). Fatores associados à baixa adesão ao tratamento farmacológico de doenças crônicas no Brasil. Revista de Saúde Pública, 50, 10s. https://doi.org/10.1590/S1518-8787.2016050006150

Tropicos. Missouri botanical garden W3 tropicos. Vascular trópico. Available in: https://www.tropicos 05 mar. 2020.

Tschiedel, B. (2014). Complicações crônicas do diabetes. Jornal Brasileiro de Medicina, $102(5), 1-10$.

Urban, A. M., Swiech, J. N. D., \& Miguel, M. D. (2019). Família Lamiaceae e a sua influência no diabetes mellitus: breve revisão. Visão Acadêmica, 20(3). http://dx.doi.org/10.5380/acd.v20i3.68288

Usha, V., Vijayammal, P. L., \& Kurup, P. A. (1989). Effect of dietary fiber from banana (Musa paradisiaca) on metabolism of carbohydrates in rats fed cholesterol free diet. Indian journal of experimental biology, 27(5), 445-449.

Yuan, L. J., Qin, Y., Wang, L., Zeng, Y., Chang, H., Wang, J., ... \& Zhu, J. D. (2016). Capsaicin-containing chili improved postprandial hyperglycemia, hyperinsulinemia, and fasting lipid disorders in women with gestational diabetes mellitus and lowered the incidence of large-for-gestational-age newborns. Clinical nutrition, 35(2), 388-393. https://doi.org/10.1016/j.clnu.2015.02.011

Zeni, A. L. B., Parisotto, A. V., Mattos, G., \& Helena, E. T. D. S. (2017). Utilização de plantas medicinais como remédio caseiro na Atenção Primária em Blumenau, Santa Catarina, Brasil. $\begin{array}{llll}\text { Ciência \& Saúde } \quad \text { Coletiva, } & \text { 22(8), }\end{array}$ https://doi.org/10.1590/1413-81232017228.18892015

\section{Copyright Disclaimer}

Copyright for this article is retained by the author(s), with first publication rights granted to the journal.

This is an open-access article distributed under the terms and conditions of the Creative Commons Attribution license (http://creativecommons.org/licenses/by/4.0/). 